\title{
Towards Gender Equality and Economic Empowerment: An Analysis of Demographic Components of Rural Women in Imo State, Southeast Nigeria
}

\author{
Emmanuella Chinenye Onyenechere*
}

Department of Geography and Environmental Management, Imo State University, Owerri, Nigeria

\begin{abstract}
This study was to analyze some demographic variables influencing the participation of rural women in the informal sector of Imo State, Nigeria. Descriptive analysis was applied on the data collected from a survey conducted in nine Local Government Areas of Imo State. Two thousand, three hundred and forty women were selected using multistage sampling. The selection of nine LG As constituted the first stage and the selection of eighteen communities constituted the second stage. After selecting these villages/communities, we chose some households from these selected villages. In the fourth stage, we selected the wife of head of household or the head of household (if female). Results obtained showed that rural informal economic activities by women are affected by the following demographic variables; age, household size, number of children, marital status, place of residence and place of work in their attempt to improve the living standard of the rural women. The results also revealed that demographic variables within rural areas are dynamic in terms of space. Since the women's activities rely heavily on family labor, the implication is the absence of a social welfare scheme, the presence of child labor, and little or no observance of the minimum wage requirement. Government policies should be formulated in this regard.
\end{abstract}

Keywords: Demographic variables, rural women, informal economic activities, Imo State, Nigeria.

\section{INTRODUCTION}

Gender and the informal sector are currently of concern to individuals, groups and governments. Prior to the 1960s, women were often regarded as an invisible factor in development. Their role and contribution were not significantly recognized; hence Anele [1] opined that the production of knowledge about African women can be used to transform social relations in the direction of gender equity and social justice.

There are a large number of women in rural farming and processing. It is these income- yielding informal economic activities by women that make them indispensable in the process of rural development. However the women in this sector are exploited, poor and overworked [2]. Presently, as more men leave for the urban areas, rural-urban migration being more selective of adult males, more and more women are left to head rural households and provide them sustenance and one wonders if their demographic strength can be a catalyst to their economic empowerment. According to Kuponiyi and Awe [3] women who fall within the age bracket of 19 to 48 years work hard to contribute to enhanced standard of living. Also the contribution of children and youths in farm work was recognized by Farooq [4] and Ijere [5]. According to Ijere [5], every family ensures that the women, children and youth engage in farm work. To consolidate this, each child at birth is given a fruit tree which he or she must tend through life.

*Address correspondence to this author at the Department of Geography and Environmental Management, Imo State University, Owerri, Nigeria; Tel: +2348033743055; E-mail: emmazob@yahoo.com
Obadan, Odusola and Akerele [6] assert that informal sector activities in many Nigerian households have become the major components of household survival strategies in the face of economic hardships. These activities enabled them to cope with their declining standards of living and counter deteriorating economic conditions. The number of children staying with a rural woman engaged in informal economic activity can determine her volume of contribution to household food security [3]. On the other hand, girls are more likely to discontinue their schooling and street trading, which utilizes child labor, often resulting in exposing children to rape and prostitution [7].

It is based on all the aforementioned interrelated problems of development, economic empowerment and standard of living and in recognition of the de-emphasis of women's role in rural development and their informal economic activity that this study sought to analyze demographic variables that influence women in their informal economic activities using Imo State as a case study.

\section{THEORETICAL BACKGROUND}

Over the past two decades the role of women in Nigeria has undergone changes. There has been a progressive change in their role from that of a housewife, whose main task is bearing children and caring for children and husband, to that of contributing to the economy. Within this period, woman's effective contribution to the home and the national economy has been faced with constraints such as lack of access to land, and capital. The perception of women in the society occasioned by the Biblical Theory of Gender Differentiation, the African Theory of Gender Differentiation, Social Stratification Theory, Cultural Theory and Genetical and 
Biological Theory has contributed to the creation of these constraints [8]. In view of developing a framework for sustainable gender policy in Nigeria, Ezewu [8] advocated a theory of gender complimentarily and procedural gender equality. The theory advocates guaranteed equality between men and women even as they play their role within the family. It believes that women and men have specific contributions to make towards national development and, as a result, the enabling environment should be created via legislation and policy formulation [9]. According to Ezewu [8] the theory of procedural gender equality ascribes equality to men and women in the place of work within the larger society and contribution to national economy. Thus, outside the marriage environment, the man should be seen as equal to the woman. The difference between them is their ability which is the only determinant of what they can do or attain.

\section{METHODOLOGY}

The main source of data for this study is information from sample survey of 2,340 women respondents. A questionnaire was used and the multi-stage sampling technique was adopted. In the first stage, nine Local Government Areas were selected from twenty-seven LGAs in the three geopolitical/senatorial zones of Imo State using the stratified sampling technique, in which each zone was taken as a stratum. In the second stage, 18 communities were randomly selected using the table of random numbers. In the third stage, systematic sampling technique was used at intervals of ten to select households for the survey in each community. In the fourth stage, the wife of the head of household was chosen as the respondent. Where the head is a polygamist, the first wife of the household is selected. Where the head of household is a woman, then she is automatically chosen. Where the sampled head of household has no wife, the next house is chosen and thereafter the sampling interval of every tenth house is adjusted and maintained. Data obtained were analyzed using descriptive statistics, particularly total, frequency counts and percentages displayed in tables.

\section{RESULTS/DISCUSSION}

Respondents' ages vary from 19 to 78 years. Table 1 show that $7.59 \%$ of the respondents in the older age category (49 to 78 years) are in Otulu community, with $6.9 \%$ in Enyiogugu and Mgbidi communities. Dikenafai, Ifakala, Isiekenesi, Nkwerre, Oguta, Okuku, Okwelle and Umunkwo communities have $6.21 \%$ each. The younger age category (19 to 48 years) is an active working group. Of the total respondents numbering $2,340,890$ or less than half are between 19 and 48 years of age. This is an indication that there is less involvement of the youthful female population in informal economic activities in Imo State.

Previous studies by Elson [10], Palmer [11], and Onyenechere [12] indicate that there is a time women get "locked in" to child care, which is observed by the near absence of women within the age brackets of 16-34 years from the labor market in most developing nations. A time when women get "locked in" is typically described by Elson [10] as phases of raising children which physically have to be undertaken by women-pregnancy, childbirth, breast feeding. It is the lack of economic independence that forces women into dependence on men for these phases of child rearing, phases which according to Elson [10] are particularly difficult to combine with income-earning. On the other hand, Palmer [11] argues that it is because of gender, and not biology, that most of the work of child rearing is done by women, which invariably often leads to the phenomenon of absent markets. Having made the same observations too, Onyenechere [12] concluded that in the informal labor market of parts of Imo State in Nigeria, there is significant difference between age and gender. However, these studies, though having accepted gender - biased inequalities have camouflaged other demographic factors that would be useful for policy formulations for women especially those in rural areas.

A greater insight into the impact of demographic variables on rural women informal economic activities can be got by examining the household size. Table $\mathbf{1}$ is informative that the household size in the study communities is large. Households with more than ten persons claim $15.15 \%$ in Orodo, $12.12 \%$ in Umuguma and $3.03 \%$ in Amaraku, Ifakala, Isiekenesi and Nguru Nwenkwo each. Of the total number of respondents 2,340, those with 7-10 persons number 1,300 and those with above 10 persons are 330 respondents. These ratios put together are more than half of the total number of respondents. It indicates a predominance of large household size. Those with $0-6$ persons in their household are only 710 respondents which is less than onethird of the total number.

The informal sector provides the greatest opportunity for employment in the developing countries [13]. The large size of the household has very serious influence on rural women informal economic activities. In Imo State family members constitute a substantial number of the workforce in the informal sector. It implies that most of the members of these large households are involved in the informal economic activities of the rural women. This is true in the area of farming and food processing, unlike artisan/handicraft informal economic activity which requires more skill and training than the other rural women informal economic activities. A number of studies carried out in the Southern states of Nigeria demonstrate that women constitute a vital labor force in the farming system especially in food crop production. A study by Nweke [14] showed that women are concerned with food crops such as cassava, maize and vegetables. Results of a study by Adebayo and Amao [15] revealed that women engaged in production of maize, cassava, melon (100\%) yam, cocoyam, cowpea $(73.9 \%)$ while those producing cowpea, maize, soyabean accounted for $(82.52 \%)$ vegetables, tomatoes and pepper $(94.73 \%)$. His finding is corroborated with that of Abdullahi [16]. Women are also involved in livestock production, goat / sheep and duck and local fowl accounted for $100 \%$ while piggery and rabbitry accounted for $59.21 \%$. It is also reported that yoruba women occupy important positions in the economic institution, not only in farming but also as traders of locally produced cash or food crops [17]. Olayiwole [18] observed that rural women in northern Nigeria participate in income yielding activities such as food processing, selling of home prepared foods and produce, and weaving. Only few members in the study area can be integrated in artisan/ handicraft activity and generally small households are more involved. 
Table 1. Percentage Distribution of Age and Household Size

\begin{tabular}{|c|c|c|c|c|c|c|c|}
\hline \multirow{2}{*}{ Communities } & \multicolumn{3}{|c|}{ Age } & \multicolumn{4}{|c|}{ Household Size } \\
\hline & Older & Younger & Total & $0-6$ & $7-10$ & Above 10 & Total \\
\hline Amaraku & 50 & 80 & 130 & 30 & 90 & 10 & 130 \\
\hline$\%$ & 3.45 & 8.99 & 12.44 & 4.23 & 6.92 & 3.03 & 14.18 \\
\hline Dikenafai & 90 & 40 & 130 & 40 & 90 & 0 & 130 \\
\hline$\%$ & 6.21 & 4.49 & 10.7 & 5.63 & 6.92 & 0 & 12.55 \\
\hline Enyiogugu & 100 & 30 & 130 & 20 & 80 & 30 & 130 \\
\hline$\%$ & 6.9 & 3.37 & 10.27 & 2.82 & 6.15 & 9.09 & 18.06 \\
\hline Ifakala & 90 & 40 & 130 & 50 & 70 & 10 & 130 \\
\hline$\%$ & 6.21 & 4.49 & 10.7 & 7.04 & 5.38 & 3.03 & 15.45 \\
\hline Isiekenesi & 90 & 40 & 130 & 40 & 80 & 10 & 130 \\
\hline$\%$ & 6.21 & 4.49 & 10.7 & 5.63 & 6.15 & 3.03 & 14.81 \\
\hline Mgbidi & 100 & 30 & 130 & 30 & 80 & 20 & 130 \\
\hline$\%$ & 6.9 & 3.37 & 10.27 & 4.23 & 6.15 & 6.06 & 16.44 \\
\hline Nguru Nwenkwo & 60 & 70 & 130 & 60 & 60 & 10 & 130 \\
\hline$\%$ & 4.14 & 7.87 & 12.01 & 8.45 & 4.62 & 3.03 & 16.1 \\
\hline Nkwerre & 90 & 40 & 130 & 50 & 50 & 30 & 130 \\
\hline$\%$ & 6.21 & 4.49 & 10.7 & 7.04 & 3.85 & 9.09 & 19.98 \\
\hline Oguta & 90 & 40 & 130 & 80 & 50 & 0 & 130 \\
\hline$\%$ & 6.21 & 4.49 & 10.7 & 11.27 & 3.85 & 0 & 15.12 \\
\hline Okuku & 90 & 40 & 130 & 10 & 100 & 20 & 130 \\
\hline$\%$ & 6.21 & 4.49 & 10.7 & 1.41 & 7.69 & 6.06 & 15.16 \\
\hline Okwelle & 90 & 40 & 130 & 30 & 80 & 20 & 130 \\
\hline$\%$ & 6.21 & 4.49 & 10.7 & 4.23 & 6.15 & 6.06 & 16.44 \\
\hline Orodo & 30 & 100 & 130 & 50 & 30 & 50 & 130 \\
\hline$\%$ & 2.07 & 11.24 & 13.31 & 7.04 & 2.31 & 15.15 & 24.5 \\
\hline Orsu-Obodo & 70 & 60 & 130 & 40 & 90 & 0 & 130 \\
\hline$\%$ & 4.83 & 6.74 & 11.57 & 5.63 & 6.96 & 0 & 12.59 \\
\hline Otulu & 110 & 20 & 130 & 10 & 100 & 20 & 130 \\
\hline$\%$ & 7.59 & 2.25 & 9.84 & 1.41 & 7.69 & 6.06 & 15.16 \\
\hline Owerre Nkwoji & 80 & 50 & 130 & 40 & 60 & 30 & 130 \\
\hline$\%$ & 5.52 & 5.62 & 11.14 & 5.63 & 4.62 & 9.09 & 19.34 \\
\hline Umuguma & 70 & 60 & 130 & 10 & 80 & 40 & 130 \\
\hline$\%$ & 4.83 & 6.74 & 11.57 & 1.41 & 6.15 & 12.12 & 19.68 \\
\hline Umuna & 60 & 70 & 130 & 90 & 40 & 0 & 130 \\
\hline$\%$ & 4.14 & 7.87 & 12.01 & 12.68 & 3.08 & 0 & 15.76 \\
\hline Umunkwo & 90 & 40 & 130 & 30 & 70 & 30 & 130 \\
\hline$\%$ & 6.21 & 4.49 & 10.7 & 4.23 & 5.38 & 9.09 & 18.7 \\
\hline Total & 1450 & 890 & 2340 & 710 & 1300 & 330 & 2340 \\
\hline
\end{tabular}

Source: Author's Fieldwork

In the context of the above discussion, studies by Bryceson [19], Soetan [20], Palmer [11] and Elson [21] as well as Elson [22] have provided the general background to gender related issues. According to them, largely as a result of S.A.Ps (Structural Adjustment Programs), diversification out of agriculture has become the norm among African rural 
populations, and female participation in the labor market as well as the sale of home-making skills among women is on the increase. Bryceson [19] observed that over the last 20 years men's labour returns from cash-cropping have diminished, undermining their role as family providers, while the attitudes of men in relation to women's incomeearning work have changed radically over the last decade. In this study unlike Bryceson [19] which documented conti- nental trends and rural change, exemplifies the demographic strength of rural women in income generating activities in the informal sector. An important point to note about women's work is that in rural areas, opportunities available to work as a formal sector wage earner is very limited so that most women in rural areas are self-employed. However, these activities which form the bulk of women's work usually go unrecorded and unnoticed [23].

Table 2. Frequency Distribution of Number of Children

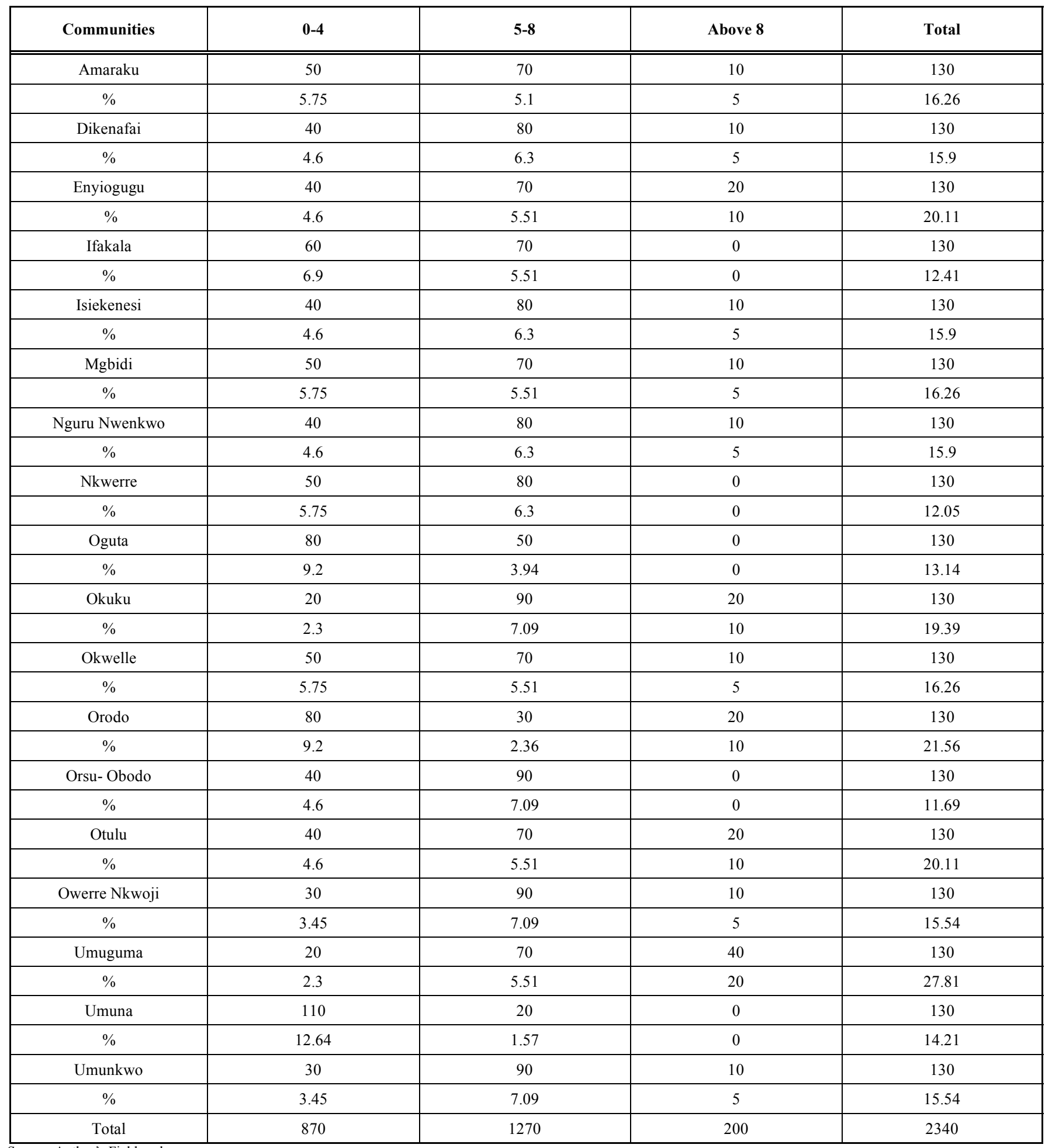


The policy implication of the involvement of household members in rural women informal economic activities is that any government that wants to improve rural women informal economic activities will effectively do so by ensuring that minimum wage requirements are observed.

There is a heavy incidence of children among the rural women. Our study shows that not all respondents have children. Most however have children. The distribution of the number of children is shown in Table 2. Communities with above 8 children category accounting for $10 \%$ are Enyiogugu, Okuku, Orodo and Otulu respectively. Only Umuguma accounts for $20 \%$ in the category of about 8 children. Of all the communities under study, Umuguma $(27.81 \%)$ has rural women with the highest number of children, whereas Orsu-Obodo $(11.69 \%)$ has rural women with the least number of children. The implication is obvious. The number of children by women has positive effects on rural women informal economic activities. While Fasakin [7] buttresses this fact, his study on child labor focused more on its gender component. It revealed that a large proportion of children who work during school hours are girls rather than boys.

In Imo state, mothers often insist on involving their children or incorporating their children into their moneymaking ventures. evidence of this can be seen by the number of children that dot the streets, nooks and crannies of rural communities of Imo state hawking food and non food items, and the dwindling number of children that are seen attending school during farm clearing and cultivating period of the planting season. It implies that a rural woman may have all her 5-8 children or above 8 children staying with her in various informal economic activities. It is income from the informal economic activities engaged in by the rural women and her children that she uses to ensure that food is provided for the family. The serious implications that this has for the education of both the women and their children is of concern to many researchers. Merrick [24] pointed out that generally employment opportunity within the informal sector seems to be influenced by such factors as sex, age, length of residence and education. He found out that female workers are quite disproportionately represented, as well as workers outside the primary age group who have not completed primary education and who are not heads of households. Okore [25] noted that the relative recency of formal education for Nigerian women and early marriage of girls in Nigeria amongst other factors are impediments to women empowerment. While Hay [26] opined that gender discrimination is higher in rural areas and at lower levels of education. Thus, education is a variable in the development process; and its influence is all pervading. Nkhoma-Wamunza [27], Acholonu [28], and Akomolafe [29] came to the same conclusion. They support girls and women to acquire education for development. Blum [30] identified education as a facilitating factor for improved extension services in rural communities. Thus, the higher the educational attainment of rural women the greater their empowerment for meaningful utilization of technology to eradicate their poverty. The fact that women in Nigeria have less access to formal education which undermines their empowerment is well documented in the studies of [20] and [29]. Access to education and an improvement of the present pattern of education provided for the rural women will certainly equip them with the appropriate technical, scientific and mechanical skills for engaging in economic production and in the social services.

The marital status of each rural woman may influence their participation in informal economic activities. The distribution of respondent's marital status is shown in Table 3; some are married, single, separated, widowed or divorced. About $33.33 \%$ of the respondents divorced are in Ifakala, another $33.33 \%$ are in Nkwerre and Otulu, and these are the only communities with divorced respondents. Of the respondents that are married, Amaraku, Enyiogugu, Isiekenesi and Mgbidi have $4.08 \%$ each. Majority of the respondents are married, out of the total figure 2340, we had 1470 married respondents. This result reveals that many of the rural women found engaged in informal economic activities are married. They engaged in these informal economic activities in - order to boost family income. About 590 respondents are widowed; these rural women are also saddled with similar responsibilities as the married ones and as such are engaged in informal economic activity to provide for the needs of the family which range from food to clothing.

Place of residence is another important demographic factor in explaining rural women informal economic activities. Though our respondents share common values and strive to satisfy their main needs not all of them reside within the villages of study. Some reside outside the sampled communities. However, majority reside in the study villages. Out of the 2,340 respondents 2,120 reside within the study communities only a few respondents (220) live outside (see Table 4). And the place of work distribution from Table 4 shows that the place of work of almost all the respondents is within the village. There are others too who work outside the village.

Rural women who farm, trade, process food and engage in craft work in their community are those who indicated within the village as place of work. Of the total respondents 2,340 served the questionnaire, 2,130 indicated within the village as their place of work. The study further revealed that 20 respondents indicated the town as their place of work, whereas 30 respondents indicated neighboring village. The main place of work of the rural women is their community, many rural women work in their community rather than outside.

The issue of rural women's place of work cannot be discussed without consideration for the rural women's other roles. Rural women have responsibility for both home/child rearing and income generation. They often prefer to choose a place of work that will certainly allow them room to engage in informal economic activity whilst at the same time being close to the home to perform their other daily duties. This explains the huge number of rural women who restrict their place of work only to the community they reside in, since family responsibilities are known to increase women's preferences for flexible occupations, however this explanation is not conclusive. Feminist (gender) theories and neoclassical theories agree that flexible jobs in terms of hours and relatively easy entry/exit/re-entry enable women to combine work and family responsibilities more easily. Work place flexibility is a tool used to obtain the business benefits of flexibility. It is also a necessary prerequisite to survival in the global market [31]. Flexibility as a concept is the greater 
Table 3. Frequency Distribution of Marital Status

\begin{tabular}{|c|c|c|c|c|c|c|}
\hline Communities & Divorced & Married & Separated & Single & Widowed & Total \\
\hline Amaraku & 0 & 60 & 0 & 50 & 20 & 130 \\
\hline Dikenafai & 0 & 80 & 0 & 20 & 30 & 130 \\
\hline$\%$ & 0 & 5.44 & 0 & 8.33 & 5.08 & 18.85 \\
\hline$\%$ & 0 & 4.08 & 0 & 4.17 & 10.17 & 18.42 \\
\hline Ifakala & 10 & 50 & 0 & 10 & 60 & 130 \\
\hline$\%$ & 33.33 & 3.4 & 0 & 4.17 & 10.17 & 51.07 \\
\hline Isiekenesi & 0 & 60 & 0 & 10 & 10 & 80 \\
\hline Nguru Nwenkwo & 0 & 90 & 0 & 10 & 30 & 130 \\
\hline$\%$ & 0 & 6.12 & 0 & 4.17 & 5.08 & 15.37 \\
\hline Nkwerre & 10 & 70 & 0 & 10 & 40 & $130^{\circ}$ \\
\hline$\%$ & 33.33 & 4.76 & 0 & 4.17 & 6.78 & 49.04 \\
\hline Oguta & 0 & 70 & 0 & 0 & 50 & 130 \\
\hline$\%$ & 0 & 4.76 & 10 & 0 & 8.47 & 113.23 \\
\hline Okuku & 0 & 100 & 100 & 0 & 30 & 130 \\
\hline$\%$ & 0 & 6.8 & 0 & 0 & 5.08 & 11.88 \\
\hline$\%$ & 0 & 6.12 & 0 & 8.33 & 3.39 & 17.84 \\
\hline Otulu & 10 & 80 & 0 & 0 & 40 & 130 \\
\hline$\%$ & 33.33 & 5.44 & 0 & 0 & 6.78 & 45.55 \\
\hline Owerre Nkwoji & 0 & 70 & 0 & 10 & 50 & 130 \\
\hline$\%$ & 0 & 4.76 & 0 & 4.17 & 8.47 & 17.4 \\
\hline Umuguma & 0 & 80 & 0 & 10 & 40 & 130 \\
\hline$\%$ & 0 & 5.44 & 0 & 4.17 & 6.78 & 16.39 \\
\hline Umuna & 0 & 130 & 0 & 0 & 0 & 130 \\
\hline$\%$ & 0 & 8.84 & 0 & 0 & 0 & 8.84 \\
\hline Umunkwo & 0 & 90 & 0 & 0 & 40 & 130 \\
\hline$\%$ & 0 & 6.12 & 0 & 0 & 6.78 & 12.9 \\
\hline Total & 30 & 1470 & 10 & 240 & 590 & 2340 \\
\hline
\end{tabular}

flexibility in working arrangements in providing more options to achieve balance between a career and a quality life. Though Standing's [32] definition of flexibility would have been more appropriate as his was contextualized in an engendered discourse. In this study women were able to take advantage of work place flexibility when they needed time off for domestic duties. Anker [33] in her study advances two possible reasons why "female" occupations tend to be 
Table 4. Frequency Distribution of Place of Residence/Work

\begin{tabular}{|c|c|c|c|c|c|c|}
\hline Communities & $\begin{array}{l}\text { Live Outside } \\
\text { Village }\end{array}$ & $\begin{array}{l}\text { Live within } \\
\text { Village }\end{array}$ & Work in City & $\begin{array}{c}\text { Work in Neigbouring } \\
\text { Village }\end{array}$ & $\begin{array}{c}\text { Work Outside } \\
\text { Village }\end{array}$ & $\begin{array}{l}\text { Work Within } \\
\text { Village }\end{array}$ \\
\hline Amaraku & 20 & 110 & 0 & 0 & 10 & 120 \\
\hline$\%$ & 9.09 & 5.19 & 0 & 0 & 6.25 & 5.63 \\
\hline Dikenafai & 0 & 130 & 0 & 0 & 10 & 120 \\
\hline$\%$ & 0 & 6.13 & 0 & 0 & 6.25 & 5.63 \\
\hline Enyiogugu & 20 & 110 & 0 & 0 & 0 & 130 \\
\hline$\%$ & 9.09 & 5.19 & 0 & 0 & 0 & 6.1 \\
\hline Ifakala & 0 & 130 & 0 & 0 & 0 & 130 \\
\hline$\%$ & 0 & 6.13 & 0 & 0 & 0 & 6.1 \\
\hline Isiekenesi & 0 & 130 & 0 & 0 & 20 & 110 \\
\hline$\%$ & 0 & 6.13 & 0 & 0 & 12.5 & 5.16 \\
\hline Mgbidi & 0 & 130 & 0 & 0 & 0 & 130 \\
\hline$\%$ & 0 & 6.13 & 0 & 0 & 0 & 6.1 \\
\hline Nguru Nwenkwo & 0 & 130 & 0 & 0 & 10 & 120 \\
\hline$\%$ & 0 & 6.13 & 0 & 0 & 6.25 & 5.63 \\
\hline Nkwerre & 0 & 130 & 0 & 0 & 0 & 130 \\
\hline$\%$ & 0 & 6.13 & 0 & 0 & 0 & 6.1 \\
\hline Oguta & 20 & 110 & 0 & 0 & 10 & 120 \\
\hline$\%$ & 9.09 & 5.19 & 0 & 0 & 6.25 & 5.63 \\
\hline Okuku & 0 & 130 & 0 & 0 & 10 & 120 \\
\hline$\%$ & 0 & 6.13 & 0 & 0 & 6.25 & 5.63 \\
\hline Okwelle & 10 & 120 & 0 & 0 & 20 & 110 \\
\hline$\%$ & 4.55 & 5.66 & 0 & 0 & 12.5 & 5.16 \\
\hline Orodo & 20 & 110 & 0 & 2 & 20 & 90 \\
\hline$\%$ & 9.09 & 5.19 & 0 & 66.67 & 12.5 & 4.23 \\
\hline Orsu- Obodo & 0 & 130 & 0 & 0 & 0 & 130 \\
\hline$\%$ & 0 & 6.13 & 0 & 0 & 0 & 6.1 \\
\hline Otulu & 10 & 120 & 0 & 1 & 10 & 110 \\
\hline$\%$ & 4.55 & 5.66 & 0 & 33.33 & 6.25 & 5.16 \\
\hline Owerre Nkwoji & 0 & 130 & 0 & 0 & 0 & 130 \\
\hline$\%$ & 0 & 6.13 & 0 & 0 & 0 & 6.1 \\
\hline Umuguma & 20 & 110 & 0 & 0 & 10 & 120 \\
\hline$\%$ & 9.09 & 5.19 & 0 & 0 & 6.25 & 5.63 \\
\hline Umuna & 70 & 60 & 0 & 0 & 10 & 120 \\
\hline$\%$ & 31.64 & 2.83 & 0 & 0 & 6.25 & 5.63 \\
\hline Umunkwo & 30 & 100 & 20 & 0 & 20 & 90 \\
\hline$\%$ & 13.64 & 4.72 & 100.0 & 0 & 12.5 & 4.23 \\
\hline \multirow{2}{*}{ Total } & 220 & 2120 & 20 & 30 & 160 & 2130 \\
\hline & \multicolumn{2}{|c|}{2340} & \multicolumn{4}{|c|}{2340} \\
\hline
\end{tabular}

flexible in terms of hours and labor turnover. It could be that women gravitate towards occupations with these charac- teristics. Or, it could be that occupations become "female", because of the type of sex stereotyping-with flexible working 
conditions, a consequence of the fact that these are "female" occupations. In view of these rural women's efforts, gender complimentarily and procedural equality should be embraced by all. and as more women in the informal sector gear up to impact positively on the lives of fellow women and other vulnerable groups, children inclusive, it is expedient that the scientific imperatives of conceptualizing, analyzing and selecting justifiable options be well streamlined and exemplified for them in the process of their empowerment and economic independence.

\section{CONCLUSION/RECOMMENDATIONS}

This paper has analyzed demographic components of rural women in the informal sector of Imo State and has discovered that there is less involvement of the youthful female population in informal economic activities, there is a predominance of large household size and children are used as labour force in the informal sector especially in the family farming enterprises because of their heavy incidence. Economic reasons underscore variations in numbers of children/family sizes aside sociological facts. It has shown that many of the rural women in the informal sector are married and engaged in economic activities in order to boost family income. And the women preferred to reside where they would take on family duties whilst engaged in their informal economic activities. From this study, there exists a great rationale for the rural women themselves while leaning on their demographic strength in informal sector activities to balance it with the adoption of labor laws and welfarist approaches. In addition, the following recommendations were made;

1. Introduction of enlightenment campaigns on economic empowerment for younger women in order to increase their participation in income yielding ventures which will ensure their self confidence and self reliance;

2. Men and women should see themselves as stakeholders in building a just society;

3. The formulation of policies that should equalize opportunities between women and men and redirect resources to those investments with the highest social returns, as well as ensure that minimum wage requirements are observed;

4. Recognizing the position of the child under the 1989 United Nations convention and the Organization for African Unity charter (Article 6 \& 27), government should encourage investment in poverty targeted social assistance programs that will provide cash grants to poor families with school age children;

5. Government should increase opportunities for women's education by making provision for the education of women with special needs e.g. the handicapped, women in the riverine areas, introducing $2 \%$ of the E.T.F (Educational Trust Fund) to pay allowances to female students, increasing the ratio of females in its implementation of U.B.E (Universal Basic Education), encouraging formal adult-basiceducation of non-literate women, ensuring that greater proportion of the curriculum content of the program for girls are geared towards the development of skills needed in the world of work today and adopt gender sensitive approach to employment and also try to tackle the problems of low income to reduce family hardship that prompt child labor;

6. To empower women also, women must change their own negative attitudes or perception of their abilities; and

7. Lastly, the views of women need to be incorporated into policy formulation.

\section{REFERENCES}

[1] Anele KA. Women and community development in Africa: The case of Akpor kingdom. Afr J Soc Policy Stud 2000; 1(1): 22-8.

[2] Onyenechere EC. Spatial analysis of rural women informal economic activities in the development Process of rural areas: A case study of Imo State. Ph.D thesis submitted accepted by the dept. of geography, University of Port Harcourt 2003.

[3] Kuponiyi FA, Awe AK. "Women, house-hold food security and poverty alleviation in Ogbomoso, Nigeria". J Bus Econ Res 2000; 1(1): $147-52$.

[4] Farooq GM. Consequences of population change for economic and manpower development. In: Udo RK, Eds. Population education source book for sub-Saharan Africa, London: Heinemann 1979.

[5] Ijere MO. Leading issues in rural development. Enugu, Lagos, Los Angeles: Acena Publishers 1992.

[6] Obadan MT, Odusola AP, Akerele WO. Strategies for revitalizing the Nigerian economy: The role of the informal sector. A paper presented on revitalizing the Nigerian economy. Ibadan: NISER 1996.

[7] Fasakin JO. A gender - based analysis of child labour in Akure metropolis, Nigeria. J Women Stud Res 2003; 1(1 \& 2): 34-9.

[8] Ezewu EE. Gender equality and national development. Keynote address presented at the national conference on sex equity in national development at the college of education in Warri, $21^{\text {st }}$ $23^{\text {rd }}$ April 1998.

[9] Odili JN, Omotor DG, Pessu EJ. "Gender equality as development framework for women integration in economic development: A theoretical perspective". Afr J Soc Policy Stud 2000; 1(2): 22-6.

[10] Elson D. Male bias in the development process. Manchester: Manchester University Press 1991.

[11] Palmer I. Gender and population in the adjustment of African economies: planning for change. Geneva: International Labour Organization 1991.

[12] Onyenechere EC. Gender relations in the informal labour market: A case study of casual labourers in Owerri metropolis, Nigeria. Research report submitted to the Director of Council for the Development of Social Science Research in Africa (CODESRIA) Gender Institute held in June at Dakar, Senegal 2008.

[13] Ojo AT. The Informal sector: Its profile and its role in the economy of Nigeria. A paper presented at the informal sector seminar organized by the Centre for Advanced Social Science (CASS), Port Harcourt April 1994.

[14] Nweke FI. Small holder cropping systems of Southeastern Nigeria: A diagnostic study. Agric Syst 1981; 7(1): 267-88.

[15] Adebayo OO, Amao JO. Rural women and household poverty alleviation in Ogo-Oluwa, Oyo State. Afr J Bus Econ Res 2000; 1(2): 200-2.

[16] Abdullahi B. Formation of women's group and implication to agriculture and rural development. A paper presented at the workshop on enhancing rural women's contribution to agriculture and rural development in Nigeria 1990.

[17] Adekanye TO. Women in agriculture in Nigeria. Report for United Nations Economic Commission for Africa, ST/ECA/ATRCW/ 81/11, Addis Ababa, Ethiopia 1981.

[18] Olayiwole CB. Rural women's participation in agricultural activities: Implications for training extension home economist. Ph.D. Dissertation, College of Home Economics, Kansas State University, Kansas 1984. 
[19] Bryceson D. Rural Africa at the crossroad: Livelihood practices and policies. ODI Natural Resources Perspectives Paper No. 52, African Studies Centre, Leiden University, The Netherlands 2000.

[20] Soetan RO. Technology and women's ventures in Nigeria's urban informal sector. Report for Carnegie Corporation of New York 1993.

[21] Elson D. The impact of structural adjustment on women: Concepts and issues. In: Onimode B, Ed. The IMF, the World Bank and the African debt, London: Zed books 1989.

[22] Elson D. Male bias in structural adjustment. In: Afshar H, Dennis $\mathrm{C}$, Eds. Women and adjustment policies in the Third World, Basingstoke: Macmillan 1992.

[23] Makinwa K. The role of women in Nigeria's socioeconomic development. In: Omu FIA, Makinwa PK, Eds. Integrated rural development in Nigeria and women's role, Ibadan: Heinemann Press 1987.

[24] Merrick TW. The informal sector in Belo Horizonte: A case study. Geneva: International Labour Organization 1973.

[25] Okore AO. Some observations on female occupational structure and labour force participation in Eastern Nigeria. In: Omu FIA, Makinwa PK, Eds. Integrated rural development in Nigeria and women's role, Ibadan: Heinemann 1987.
[26] Hay MJ. Women as owners, occupants and managers of property in colonial Western Kenya. In: Hay MJ, Wrights M, Eds. African women and the law: Historical perspectives, Boston Massachusetts: Boston University African Studies Center 1982.

[27] Nkhoma-Wamunza A. The informal sector: A strategy for survival in Tanzania. In: Taylor DFR, Mackenzie F, Eds. Development from within-survival in rural Africa. London and New York: Routledge.

[28] Acholonu R. Gender in the ivory tower: Nigerian perspective. WOREC J Gend Stud 2003; 1(2): 1-15.

[29] Akomolafe CO. Open and distance learning as a mechanism for women empowerment in Nigeria. A paper delivered at the Fourth Pan Commonwealth Forum on Open Learning 2006.

[30] Blum LM. Between feminism and labour. Berkeley: University of California Press 1991.

[31] Reilly P. Flexibility at work: Balancing the interests of employers and employees. Hampshire: Gower Publishing Limited 2001.

[32] Standing G. Global feminization through flexible labour in labour market analysis and employment planning, Working Paper No. 31 Geneva: International Labour Organisation 1989.

[33] Anker R. Gender and jobs: sex segregation of occupations in the World. Geneva: International Labour Organization 1998.

Received: January 27, 2009

Revised: February 20, 2009

Accepted: February 21, 2009

(C) Emmanuella Chinenye Onyenechere; Licensee Bentham Open.

This is an open access article licensed under the terms of the Creative Commons Attribution Non-Commercial License (http: //creativecommons.org/licenses/by$\mathrm{nc} / 3.0 /$ ), which permits unrestricted, non-commercial use, distribution and reproduction in any medium, provided the work is properly cited. 